\title{
Characterization and selection of passion fruit (yellow and purple) accessions based on molecular markers and disease reactions for use in breeding programs
}

\author{
C. B. M. Cerqueira-Silva $\cdot$ O. N. Jesus • \\ E. J. Oliveira - E. S. L. Santos • A. P. Souza
}

Received: 12 June 2014/Accepted: 10 August 2014/Published online: 24 August 2014

(C) The Author(s) 2014. This article is published with open access at Springerlink.com

\begin{abstract}
Passiflora edulis Sims, which is native to South America, stands out as a passion fruit species with major potential for fruit production and marketing. This species is popularly known as yellow or purple passion fruit, depending on the color of the fruits produced. Brazil is the major worldwide producer of passion fruit; however, the average productivity of the country is low compared with its potential for culture. Fungal, bacterial and viral pathogens are among the factors limiting the productivity of passion fruit. Furthermore, no existing
\end{abstract}

Electronic supplementary material The online version of this article (doi:10.1007/s10681-014-1235-9) contains supplementary material, which is available to authorized users.

C. B. M. Cerqueira-Silva · E. S. L. Santos

Dept. Ciências Exatas e Naturais, Universidade Estadual

do Sudoeste da Bahia, Itapetinga, BA, Brazil

C. B. M. Cerqueira-Silva · E. S. L. Santos ·

A. P. Souza $(\square)$

Centro de Biologia Molecular e Engenharia Genética,

Universidade Estadual de Campinas, Campinas, SP,

Brazil

e-mail: anete@unicamp.br

O. N. Jesus · E. J. Oliveira

Centro Nacional de Pesquisa em Mandioca e Fruticultura, Empresa Brasileira de Pesquisa Agropecuária,

Cruz das Almas, BA, Brazil

\section{A. P. Souza}

Dept. Biologia Vegetal, Universidade Estadual de

Campinas, CampinasSão Paulo, Brazil cultivars exhibit both productivity and resistance to disease. To select genetic material that will be useful for core collections and for increasing the genetic resistance of passion fruit cultivars to pathogens, we characterized 36 accessions based on 23 microsatellite loci and six variables related to the reactions to three diseases (woodiness virus, scab and anthracnose). We identified 127 alleles (an average of 5.52 alleles per locus), $30 \%$ of which were private for yellow or purple passion fruit accessions. Analysis of variance and mean comparison tests indicated differences in five of the six variables $(p<0.05$, Scott-Knott test). Differences between the average reactions of the yellow and purple passion fruit accessions were also observed for the symptoms of woodiness virus and anthracnose ( $p<0.05$, Mann-Whitney test).Together with these results, molecular and phenotypic estimates allowed the identification of groups of preferential accessions for use in breeding programs, for example, accessions BGP029, 071, 168, 205 and 277.

Keywords Germplasm bank - Microsatellite marker $\cdot$ Passiflora $\cdot$ Pre-breeding $\cdot$ Resistance

\section{Introduction}

Passion fruit (Passiflora spp.) is grown in different parts of the world, primarily in tropical regions, with Brazil, Colombia, Peru and Ecuador representing the 
major producers of these fruits (Borges et al. 2005). Although Brazilian production has varied, it has generally increased in recent decades, with an average production of 676,000 tons being recorded during the last 10 years (IBGE 2012). However, despite dominating global passion fruit production, Brazilian productivity has remained stable (approximately 14 tha $^{-1}$ year $^{-1}$ ) and well below this crop's productivity potential, which is estimated at approximately 50 tha $^{-1}$ year $^{-1}$ (Meletti et al. 2005).

Different factors contribute to the low productivity of passion fruit in Brazil, such as the occurrence of fungal, bacterial and viral pathogens. Records in the literature indicate the occurrence of numerous pathogens associated with passion fruit crops. Discussions of advances and perspectives related to the primary diseases that affect passion fruit cultivation (such as fusariosis, scab, anthracnose, bacteriosis, and woodiness virus) are also available in the literature (Cerqueira-Silva et al. 2014a; Silva et al. 2013; Faleiro et al. 2011; Meletti et al. 2005; Faleiro et al. 2005).

Recent and ongoing research has aimed to identify or to generate genotypes and hybrids with greater resistance to the diseases that affect passion fruit. To identify sources of resistance to diseases, we highlight studies addressing the characterization of passion fruit varieties and cultivars (Batistti et al. 2013; Fischer et al. 2010; Junqueira et al. 2003), as well as accessions maintained in collections and germplasm banks (Oliveira et al. 2013; Silva et al. 2013; Cerqueira-Silva et al. 2008; Junqueira et al. 2006). In general, the results presented in the published literature vary, indicating the differing susceptibilitiesof the evaluated cultivars and the broad genetic variability of the specimens in germplasm banks, for both $P$. edulis and wild passion fruit species.

Various investigators have indicated a need for research that contributes to advancing genetic breeding programs for passion fruit andto releasing cultivars that combine resistance characteristics (Faleiro et al. 2011; Meletti et al. 2005; Faleiro et al. 2005; Junqueira et al. 2003). Promising results associated with identifying potential sources of resistance have been observed in some accessions of $P$. edulis for resistance to bacteriosis and anthracnose; in accessions of wild species such as $P$. actinia, $P$. setacea and $P$. coccinea for resistance to virosis; in $P$. odontophylla, $P$. gibertii, $P$. caerulea, $P$. actinia, and $P$. mucronatafor resistance to bacteriosis; andin $P$. serrato-digitata, $P$. gibertii, $P$. coccinea, $P$. actinia, $P$. setacea, $P$. nitida, and $P$. caerulea for resistance to anthracnose (Oliveira et al. 2013; Faleiro and Junqueira 2009; Faleiro et al.2005). However, basic information associated with agronomic evaluations and the available estimates of genetic variability remain limited for many of these materials. Therefore, pre-breeding activities, such as the prospecting and characterization of accessions, are required to maintain the variability in collections, and germplasm banks could be effectively used as a genetic resource allowing expansion of the genetic basis of passion fruit breeding programs (Faleiro et al. 2011; Meletti et al. 2005; Faleiro et al. 2005).

Costs are generally high for research activities specifically associated with pre-breeding (such as performing agronomic characterizations, determining diversity estimates and identifying preferred crossings), and the time required to obtain results is considerable (Nass 2011; Nass and Paterniani 2000). The use of molecular markers is fundamentally important for enhancing the amount of information generated and for reducing the time required to obtain results (Ferreira and Rangel 2011). In this context, we note a considerable increase in research devoted to obtaining estimates of genetic variability using molecular markers in both commercial (Ortiz et al. 2012; Costa et al. 2012; Cerqueira-Silva et al. 2010a; Bellon et al. 2007; Viana et al. 2003) and wild passion fruit species (Cerqueira-silva et al. 2010b, c, 2012a; Junqueira et al. 2007). These studies have identified low variability among commercial accessions of $P$. edulis and generally wide variability among wild accessions of passion fruit, reinforcing the potential for the use of these materials as a resource in breeding programs.

Significant advances in research devoted to constructing genetic maps and identifying regions associated with resistance control, at least for Xanthomonas axonopodis pv. passiflorae yellow passion fruit, have occurred since 2002 (Lopes et al. 2006; Carneiro et al. 2002). In this context, with the addition of a new set of microsatellite markers, the first integrated map of passion fruit was published for $P$. edulis (Oliveira et al. 2008), providing the ability to use this information for identifying quantitative trait loci (QTLs). The construction of agenetic map using multiple markers, such as amplified fragment length polymorphisms (AFLPs), microsatellite-AFLPs (M-AFLPs), simple sequence repeats (SSRs), resistance gene analogs (RGAs) and 
single nucleotide polymorphisms (SNPs), has also been reported for P. alata (Pereira et al. 2013). In addition, recent efforts associated with developing and characterizing bacterial artificial chromosomes (BACs) have led to the construction of physical maps for passion fruit (Santos 2013).

Although recent, the inclusion of molecular markers in breeding programs for passion fruit is already occurring at different stages (Faleiro et al. 2012). Molecular markers are currently being employed for purposes such as identifying ornamental hybrids and improving fruit production, using both dominant and co-dominant markers (Santos et al. 2012; Conceição et al. 2011; Junqueira et al. 2008). Molecular markers have also contributed to the monitoring of genetic variability in segregant populations subjected to cycle selection (Reis et al. 2012, 2011; Costa et al. 2012) and backcrossing (Fonseca et al. 2009). These referenced works, together with the growing number of results concerning the identification and characterization of microsatellite markers in passion fruit species (Cerqueira-Silva et al. 2014b; Penha et al. 2013; Cazé et al. 2012; Cerqueira-Silva et al. 2012b; Padua et al. 2005; Oliveira et al. 2005) should effectively contribute to advancing breeding programs and to proposing strategies for managing and conserving passion fruit.

Considering the need for research that contributes to the genetic improvement of passion fruit cultivars, thereby increasing resistance to major diseases affecting the fruits, in the present study, we characterized $P$. edulis (yellow and purple shell) accessions based on molecular markers and their reactions to diseases to select genetic material that will be useful for establishing core collections and working populations dedicated to understanding and increasing genetic resistance in passion fruit cultivars.

\section{Materials and methods}

Biological material

Thirty-six accessions were used in this study, one of which was a cultivated passion fruit variety (BRS Gigante Amarelo). Most of the accessions (34) originated from 18 cities distributed across five Brazilian states, and the remaining two accessions originatedfrom Venezuela and Portugal (Fig. 1) (Supplementary Material-SM 1). The accessions encompassed popularly known variations, such as purple and yellow passion fruits, both of which are found in P. edulis Sims (Bernacci et al. 2008). Alltheaccessions belong to the Active Germplasm Bank for Passiflora of Empresa Brasileira de Pesquisa Agropecuária (EMBRAPA) Cassava and Fruits (CNPMF/EMBRAPA), Cruz das Almas, Bahia, Brazil $\left(12^{\circ} 48^{\prime} 38^{\prime \prime} \mathrm{S}\right.$ and $\left.39^{\circ} 06^{\prime} 26^{\prime \prime} \mathrm{W}\right)$.

Characterization of microsatellite locus polymorphisms

Genomic DNA was isolated from fresh leaves using the cetyltrimethylammonium bromide (CTAB) method (Doyle and Doyle 1990) and stored in duplicate samples in an ultra-cold freezer at the Laboratory of Applied Molecular Genetics of the Universidade Estadual do Sudoeste da Bahia (UESB), Itapetinga, Bahia, and at the Laboratory of Molecular Genetic Analysis of the Universidade Estadual de Campinas (UNICAMP), Campinas, São Paulo. Every accession was represented by three plants (grown from seeds of fruits obtained through controlled pollination). DNA samplequality was assessed via electrophoresis $(90 \mathrm{~V}$ electric current for $90 \mathrm{~min})$ in $1 \%\left(\mathrm{~m} \mathrm{v}^{-1}\right)$ agarose gels and staining with ethidium bromide. DNA concentrations (ng $\mu \mathrm{L}^{-1}$ ) were estimated based on comparisons with known quantities of lambda phage DNA (undigested lambda DNA).

A set of 23 SSR loci was used, 11of which came from theseries $m P c$-UNICAMP, $m P e$-UNICAMP and $m P s-U N I C A M P$ (Cerqueira-Silva et al. 2012b, 2014b) and 12 fromthe series USP (Oliveira 2006). Polymerase chain reaction (PCR) assays to obtain diversity estimates were conducted in a final volume of $15 \mu \mathrm{L}$, containing $12 \mathrm{ng}$ of template DNA, $0.4 \mathrm{mM}$ each primer (reverse and forward) and 1.0 U of Taq DNA polymerase (Invitrogen Co, Carlsbad, CA, USA). For other reagents (dNTP concentrations, $\mathrm{MgCl}_{2}$ and buffers) and amplification conditions (annealing temperatures and characteristics of PCR cycling), the exact procedures described in the original articles addressing theidentification and characterization of the lociwere used.

The products were initially visualized through horizontal electrophoresis in $3 \%(\mathrm{~m} / \mathrm{v})$ agarose gels run in $0.5 \times \mathrm{TBE}$ and stained with ethidium bromide to confirm amplification and subsequently through vertical electrophoresis in denaturing $6 \%\left(\mathrm{~m} \mathrm{v}^{-1}\right)$ polyacrylamide gels run in $1 \times \mathrm{TBE}$ and stained with silver 
(a)

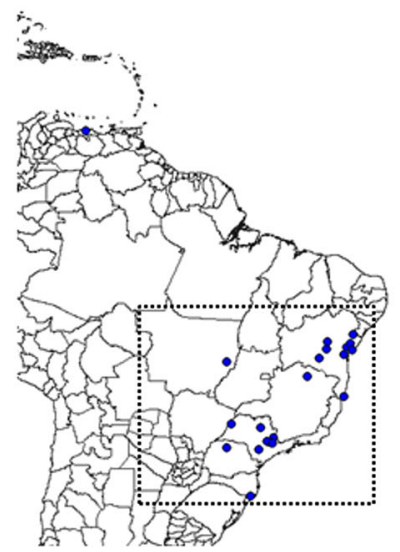

(b)

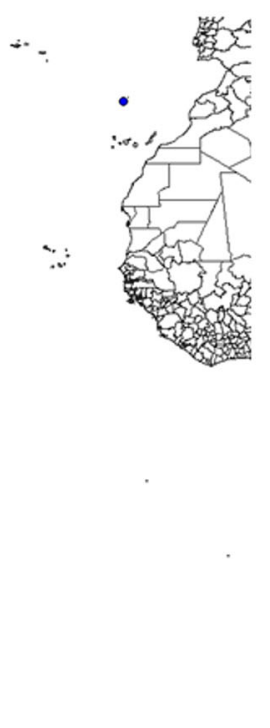

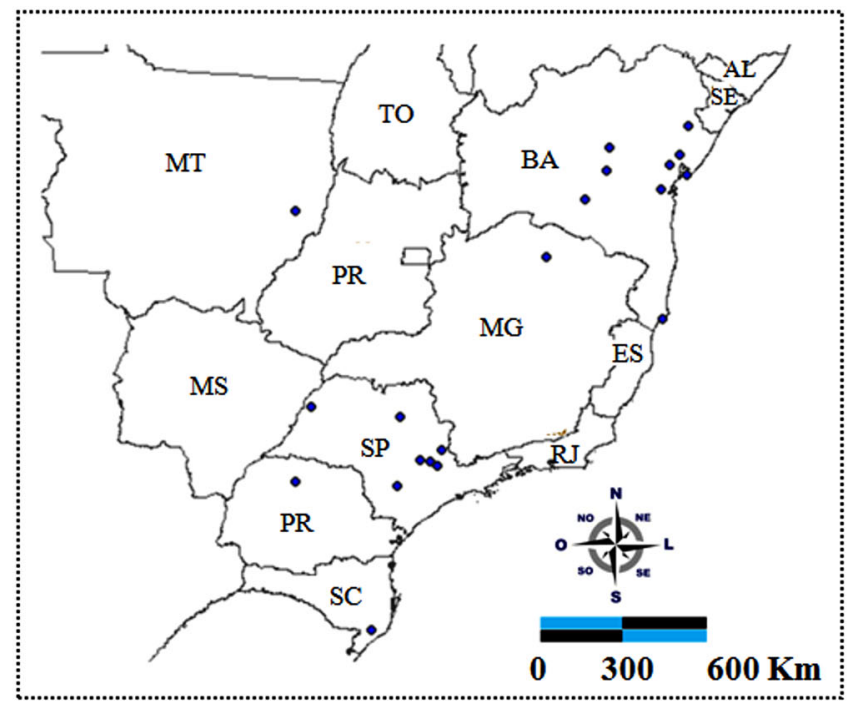

Fig. 1 Geographical areas where passion fruit (Passiflora edulis Sims) accessionswere collected (a), highlighting areas of the Brazilian territory where most of the collections were performed (b). The blue dots correspond to sampled areas. (Color figure online)

nitrate to characterize the amplification profiles. The sizes of the products were determined using a 10-bp DNA ladder (Invitrogen), and the repeatability of the electrophoretic profiles was evaluated by repeating the vertical electrophoresis runs for a minimum of $10 \%$ of the samples considered. Characterization of the disease reactions
of the passion fruit accessions

Experimental field data were collected as part of the characterization activities (and subsequent stages of the pre-breeding program) conducted on the Passiflora Germplasm Bank of EMBRAPA Cassava and Fruits from April to July in 2009, which are the months with the highest natural incidence of disease. Artificial inoculations had not been previously performed, and a randomized block design was adopted, with four repeats and ten plants per parcel. The spacing between rows was $2.6 \mathrm{~m}$, while that between plants was $3.7 \mathrm{~m}$, and a system of vertical trellises was used for the conduction of branches.

The evaluation of symptoms was based on previously developed note scales that areroutinely used to characterize the reactions of passion fruit to woodiness virus (Table 1) (Novaes and Rezende 1999), scab and anthracnose (Table 2) (Junqueira et al. 2003). Then,
Table 1 Scale used to quantify symptoms of woodiness virus in the leaves and fruits of 36 passion fruit (Passiflora edulis Sims) accessions from the active germplasm bank of EMBRAPA Cassava and Fruits, Cruz das Almas, Bahia, Brazil

\begin{tabular}{|c|c|c|c|}
\hline \multirow{2}{*}{$\begin{array}{l}\text { Note } \\
\text { scale }\end{array}$} & \multicolumn{3}{|c|}{ Symptoms of woodiness disease in passion fruit } \\
\hline & Leaves & Fruits & Plants \\
\hline 1 & No symptoms & $\begin{array}{l}\text { No } \\
\text { symptoms }\end{array}$ & $\begin{array}{l}\text { Few leaves with } \\
\text { mild mosaic and } \\
\text { wrinkling }\end{array}$ \\
\hline 2 & $\begin{array}{l}\text { Mild mosaic, no } \\
\text { deformation } \\
\text { of leaves }\end{array}$ & $\begin{array}{l}\text { Mildly } \\
\text { deformed }\end{array}$ & $\begin{array}{l}\text { Moderate quantity } \\
\text { of leaves with } \\
\text { mild mosaic and } \\
\text { wrinkling }\end{array}$ \\
\hline 3 & $\begin{array}{l}\text { Mild mosaic, } \\
\text { blisters and } \\
\text { deformation } \\
\text { of leaves }\end{array}$ & $\begin{array}{l}\text { Totally } \\
\text { deformed, } \\
\text { fruit } \\
\text { woodiness, } \\
\text { spots }\end{array}$ & $\begin{array}{l}\text { Large quantity of } \\
\text { leaves with } \\
\text { mosaic and severe } \\
\text { wrinkling }\end{array}$ \\
\hline 4 & $\begin{array}{l}\text { Severe mosaic, } \\
\text { blisters and } \\
\text { deformation } \\
\text { of leaves }\end{array}$ & - & - \\
\hline
\end{tabular}

the observed data were employed to quantify the reactions of the accessions to each of the three diseases considered in this study.

To evaluate disease symptoms caused by woodiness virus, scab and anthracnoseon fruits, 15 fruits 
Table 2 Scale used to quantify symptoms of scab on the fruits and branches and anthracnose on the fruits in 36 passion fruit (Passiflora edulis Sims) accessions from the active germplasm bank of EMBRAPA Cassava and Fruits, Cruz das Almas, Bahia, Brazil

\begin{tabular}{|c|c|}
\hline $\begin{array}{l}\text { Note } \\
\text { scale }\end{array}$ & Symptoms of scab and anthracnose on passion fruit \\
\hline 1 & No symptoms \\
\hline 2 & $\begin{array}{l}\text { Surface of the fruit/branch covered with lesions } \\
\leq 10 \%\end{array}$ \\
\hline 3 & $\begin{array}{l}\text { Surface of the fruit/branch covered with lesions } \\
\text { between } 11 \text { and } 30 \%\end{array}$ \\
\hline 4 & $\begin{array}{l}\text { Surface of the fruit/branch covered with lesions } \\
>30 \%\end{array}$ \\
\hline
\end{tabular}

were randomly collected at the beginning of the maturation process. To assess the severity of scab on branches, we examined three young branches on each of five central plants in the plot. Finally, to assess the severity of woodiness virus symptoms in leaves, the fifth leaf of young branches and the overall distribution of woodiness virus symptoms were evaluated in five central plants in the plot.

Data analysis and diversity estimates

Initially, we performed a descriptive statistical analysis of the 23 SSR loci considering all 36 accessions (with each accession represented by three plants). The number of alleles per locus (Na), observed heterozygosity $\left(\mathrm{H}_{\mathrm{O}}\right)$, expected heterozygosity $\left(\mathrm{H}_{\mathrm{E}}\right)$ and fixation index $(\mathrm{F})$ were calculated using the GenAlEx v. 6.5.3 program (Peakall and Smouse 2012), and the polymorphic information content (PIC) of each locus was calculated using the macro MSTools application (Excel Microsatellite Toolkitv. 3.1) in Microsoft Excel 2007. The data obtained from the assessment of disease symptoms based on the note scales were standardized (each observed value was divided by the highest value in each scale) such that all observations ranged from 0 (resistant) to 1 (susceptible), regardless of the disease evaluated. The data were analyzed using descriptive statistics by estimating the mean and extreme values and the variance of the samples using BIOSTAT 5.3 software (Ayres et al. 2007).

Diversity estimates were performed for the molecular data based on the modified Rogers' distance (Wright 1978), with each accession being examined as a group composed of three plants, and the agronomic data concerning disease reactions were assessed based on the Mahalanobis distance; these analyses were conducted using the TFPGA (Miller 1997) and GENES (Cruz 2008, 2006) programs, respectively. Clusters were graphically represented as dendrograms using the unweighted pair-group method with arithmetic mean (UPGMA) clustering algorithm, which was implemented in DARwin software (Perrier and Jacquemoud-Collet 2006). The efficiencies of the cluster matrices were evaluated through bootstrap analysis (1,000 resampling values), and the correlation between the matrices was verified using the Mantel test (with 10,000 simulations), which was implemented in the GENES program (Cruz 2006).

Comparisons regarding the intensity of the symptoms presented by the yellow and purple passion fruit accessions for each of the evaluated diseases were performed based on the Mann-Whitney test using BIOSTAT 5.3 software (Ayres et al. 2007). Diversity and genetic structure were also assessed between the yellow and purple passion fruit accessions. Both parameters were estimated using the GenAlEx v. 6.5.3 program (Peakall and Smouse 2012) based on the occurrence of private alleles, the value of $\mathrm{Nei}^{\prime} \mathrm{sG}_{\mathrm{st}}$ and the percentage of variation between groups through analysis of molecular variance (AMOVA).

Selection of accessions and establishment of core and working collections

The accessions were sorted based on the intensity of the observed symptoms for all six studied variables and subjected to analyses of variance (ANOVAs), and univariate grouping tests (Scott-Knott), which were implemented in the GENES program (Cruz 2006, 2008).Using the ANOVA results as a basis, the coefficient of variation $(\mathrm{CV})$ and the broad-sense heritability (BSH) for each variable were also estimated. The same analysis procedures were applied jointly considering the variables related to each disease, where the values used in the analysis represented the average values presented by the accessions for the three variables related to woodiness virus (in leaves, fruits and plants) and the average values for the two variables related to scab (on fruits and branches).

Considering the ranks of the accessions, which were based on the severity of symptoms for the three diseases, groups were formed that encompassed 25 , 50,75 and $100 \%$ of the accessions in ascending order 
Table 3 Characteristics of the microsatellite markers used in the genotyping of 36 passion fruit (Passiflora edulis Sims) accessions from the germplasm bank of EMBRAPA Cassava and Fruits, Cruz das Almas, Bahia, Brazil
$\mathrm{Na}$ number of alleles, $H_{O}$ observed heterozygosity, $H_{E}$ expected heterozygosity (Nei's genetic diversity), PIC polymorphic information content, $F$ fixation index

a Confidence interval estimated through bootstrapping $(100,000$ simulations)

\begin{tabular}{|c|c|c|c|c|c|}
\hline Markers & $\mathrm{Na}$ & $\mathrm{H}_{0}$ & $\mathrm{H}_{\mathrm{E}}$ & PIC & $\mathrm{F}$ \\
\hline mPc-UNICAMP11 & 2 & 0.15 & 0.14 & 0.13 & -0.08 \\
\hline mPs-Unicamp01 & 7 & 0.62 & 0.73 & 0.68 & 0.15 \\
\hline mPs-Unicamp02 & 7 & 0.58 & 0.73 & 0.68 & 0.2 \\
\hline mPs-UNICAMP05 & 3 & 0.21 & 0.29 & 0.27 & 0.3 \\
\hline mPs-Unicamp06 & 4 & 0.82 & 0.66 & 0.59 & -0.25 \\
\hline mPs-UNICAMP09 & 2 & 0.01 & 0.01 & 0.01 & 0 \\
\hline mPs-Unicamp10 & 4 & 0.08 & 0.17 & 0.16 & 0.49 \\
\hline mPs-UNICAMP15 & 2 & 0.14 & 0.13 & 0.12 & -0.08 \\
\hline mPs-UNICAMP16 & 3 & 0.45 & 0.53 & 0.45 & 0.15 \\
\hline mPe-UNICAMP01 & 2 & 0.03 & 0.05 & 0.04 & 0.39 \\
\hline mPe-Unicamp02 & 4 & 0.44 & 0.43 & 0.37 & -0.02 \\
\hline USP 07 & 16 & 0.81 & 0.87 & 0.86 & 0.06 \\
\hline USP 08 & 6 & 0.36 & 0.57 & 0.52 & 0.36 \\
\hline USP 15 & 8 & 0.6 & 0.69 & 0.64 & 0.13 \\
\hline USP 16 & 9 & 0.62 & 0.77 & 0.75 & 0.19 \\
\hline USP 17 & 4 & 0.48 & 0.51 & 0.46 & 0.06 \\
\hline USP 18 & 9 & 0.69 & 0.68 & 0.64 & -0.02 \\
\hline USP 19 & 9 & 0.52 & 0.8 & 0.77 & 0.34 \\
\hline USP20 & 3 & 0.41 & 0.39 & 0.32 & -0.06 \\
\hline USP 23 & 6 & 0.35 & 0.75 & 0.72 & 0.54 \\
\hline USP 24 & 8 & 0.66 & 0.73 & 0.68 & 0.09 \\
\hline USP 42 & 3 & 0.07 & 0.08 & 0.08 & 0.19 \\
\hline USP 58 & 6 & 0.59 & 0.62 & 0.55 & 0.04 \\
\hline Average & 5.52 & 0.42 & 0.49 & 0.46 & 0.14 \\
\hline Confidence interval $^{\mathrm{a}}$ & $4.3-6.7$ & $0.32-0.51$ & $0.38-0.58$ & $0.34-0.54$ & $0.06-0.21$ \\
\hline
\end{tabular}

of symptom intensity. The number of microsatellite alleles maintained in each group that was formed was estimated using the GenAlEx v. 6.5.3 program (Peakall and Smouse 2012). Estimations for the core collections based only on molecular data were also performed with the COREFINDER program using 99 interactions (Cipriani et al. 2010). Statistical analyses were conducted considering the probability level of significance to be $5 \%(p<0.05)$.

\section{Results}

Genetic diversity based on microsatellite markers

We identified 127 alleles among the 36 passion fruit accessions (with an average of 5.52 alleles per assessed locus), and an excess of homozygotes was detected based on the observed heterozygosities $\left(\mathrm{H}_{\mathrm{o}}\right.$; mean value $=0.42$ ) and the expected heterozygosities
$\left(\mathrm{H}_{\mathrm{E}}\right.$, Nei's genetic diversity; mean value $\left.=0.49\right)$ (Table 3). The PIC presented a mean value of 0.46 (ranging from 0.01 to 0.86 ), and the fixation index (F) values were positive for most of the SSR loci (70 \%), with a mean value of 0.14 being obtained (ranging from -0.25 to 0.54 ). No genetic structure was observed between the purple and yellow passion fruit accessions (Nei's $\mathrm{G}_{\mathrm{st}}=0.012$ ), and only $1 \%$ of the existing diversity occurred among the groups of yellow and purple passion fruit (AMOVA based on 999 permutations). Approximately $30 \%$ of the alleles were identified as private, corresponding to 34 and five alleles restricted to accessions of yellow and purple passion fruit, respectively.

Characterization of the disease reactions of the passion fruit accessions

The symptom-associated values observed for the six variables related to the reactions of the accessions to 


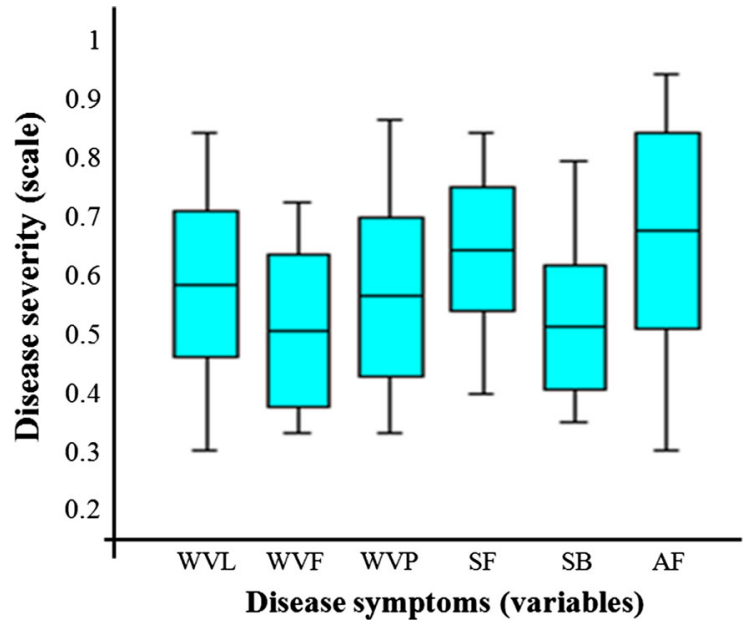

Fig. 2 Box-plot representing the average, standard deviation and extreme values observed for the symptoms of woodiness virus in leaves (WVL), woodiness virus in fruits (WVF), woodiness virus in plants (WVP), scab on fruit (SF), scab on branches (SB), and anthracnose on fruits (AF) in 36 passion fruit (P. edulis Sims) accessions

the three analyzed diseases ranged from 0.30 to 0.95 (when the data were standardized to range from 0 to 1 ). The average values observed in the 36 accessions for each variable were as follows: 0.58 for woodiness virus in leaves, 0.50 for woodiness virus in fruits, 0.57 for woodiness virus in plants, 0.65 for scab on fruit, 0.51 for scab on branches, and 0.68 for anthracnose on fruits (Fig. 2).

The ANOVA identified significant differences for all six variables $(p<0.05)$, and the univariate test for the comparison of means (Scott-Knott) allowed the accessions to be classified into two distinct groups in terms of the severity of symptoms (identified with the letters a and b) for four of the six variables considered (symptoms of woodiness virus in leaves, woodiness virus in fruits, woodiness virus in plants and scab on fruit) (Table 4). No significant difference was observed between the average values of the variables related to scab on branches and anthracnose. The correlations between the six variables were extremely low $(-0.12<\mathrm{r}<0.36)$, with the only significant correlations being detected between the symptoms of scab on fruits and woodiness virus on fruits (Supplementary Material-SM 2). Finally, when the variables related to each disease were analyzed together, we identified a significant difference between the groups for the symptoms related to woodiness virus $(p<0.05$, ScottKnott test), but not for those related to scab (Table 4).
Estimation of diversity, grouping and selection of accessions

The modified Rogers' distance (Wright 1978) presented a mean value of $0.41 \pm 0.07$ among the pairs of accessions evaluated using SSR markers, with the values ranging from 0.21 to 0.62 . Based on the disease reaction data, a mean value of $5.06 \pm 3$ was observed for the Mahalanobis distance among the pairs of accessions, with a range of 0.38-22.9. Details regarding the distances observed between pairs of accessions for each of the estimations are presented in dendrograms (Fig. 3). The Mantel correlation test was significant for the two distance matrices $(p<0.001)$; however, the value of the correlation coefficient was low ( $\mathrm{r}=0.16$ with 10,000 simulations).

A significant difference in the mean values of symptoms was observed between the groups formed based on different percentages of selection $(25,50$ and $75 \%$ of accessions per group) and based on the total set of accessions evaluated ( $p<0.05$; MannWhitney test) (Table 5). The number of alleles present in each group ranged from 98 (in the group formed by the nine accessions showingthe lowest intensity of symptoms for anthracnose) to 125 (in the group formed by the 27 accessions showingthe lowest intensity of symptoms for scab), representing 77 and $98 \%$, respectively, of the total alleles identified in the 36 characterized accessions. For all groups, the values of Nei's genetic diversity were similar, ranging from 0.48 to 0.52 (Table 5). Additionally, five accessions were identified (BGP029, $071,168,205,277)$ as being present in both of the groups displaying lower intensities of symptoms (groups 1 and 2) for the three evaluated diseases. The average values for the observed symptoms differed significantly between the accessions of yellow passion fruit $(0.57$ for woodiness virus, 0.59 for scab, and 0.66 for anthracnose) and purple passion fruit ( 0.51 for woodiness virus, 0.58 for scab, and 0.72 for anthracnose) for woodiness virus ( $p<0.05$, MannWhitney test), but not for scab and anthracnose ( $p<0.1$, Mann-Whitney test) (Table 6).

The estimates performed for the core collections with the COREFINDER program (Cipriani et al. 2010) indicated that four and 16 accessions represented 70 and $100 \%$ of the genetic diversity of alleles, respectively (Fig. 4). 
Table 4 Average values observed in 36 passion fruit (P. edulis Sims) accessions for symptoms of woodiness virus in leaves (WVL), woodiness virus in fruits (WVF), woodiness virus in plants (WVP), scab on fruit (SF), scab on branches (SB), and anthracnose on fruits (AF) and the average symptoms observed for woodiness virus and scab
Averages followed by the same letter within a column do not significantly differ by the Scott-Knott test at a $5 \%$ probability

$\mathrm{CV}$ coefficient of variation, $B S H$ broad-sense heritability

a Details of the accessions are available in the Supplementary Material SM 1

\begin{tabular}{|c|c|c|c|c|c|c|c|c|}
\hline \multirow[t]{2}{*}{ Accessions ${ }^{\mathrm{a}}$} & \multicolumn{4}{|c|}{ Woodiness virus } & \multicolumn{3}{|l|}{ Scab } & \multirow{2}{*}{$\begin{array}{l}\text { Anthracnose } \\
\text { AF }\end{array}$} \\
\hline & WVL & WVF & WVP & Average & $\mathrm{SF}$ & SB & Average & \\
\hline BGP007 & $0.65 \mathrm{a}$ & $0.60 \mathrm{a}$ & $0.60 \mathrm{~b}$ & $0.62 \mathrm{a}$ & $0.85 \mathrm{a}$ & $0.35 \mathrm{a}$ & $0.60 \mathrm{a}$ & $0.70 \mathrm{a}$ \\
\hline BGP009 & $0.65 a$ & $0.73 a$ & $0.53 b$ & $0.64 \mathrm{a}$ & $0.60 \mathrm{~b}$ & $0.40 \mathrm{a}$ & $0.50 \mathrm{a}$ & $0.55 \mathrm{a}$ \\
\hline BGP017 & $0.65 \mathrm{a}$ & $0.67 \mathrm{a}$ & $0.47 \mathrm{~b}$ & $0.59 \mathrm{a}$ & $0.50 \mathrm{~b}$ & $0.55 a$ & $0.53 \mathrm{a}$ & $0.85 \mathrm{a}$ \\
\hline BGP022 & $0.75 a$ & $0.33 b$ & $0.53 b$ & $0.54 b$ & $0.45 b$ & $0.40 \mathrm{a}$ & $0.43 \mathrm{a}$ & $0.90 \mathrm{a}$ \\
\hline BGP023 & $0.65 a$ & $0.40 \mathrm{~b}$ & $0.40 \mathrm{~b}$ & $0.48 b$ & $0.70 \mathrm{a}$ & $0.55 \mathrm{a}$ & $0.63 \mathrm{a}$ & $0.75 \mathrm{a}$ \\
\hline BGP028 & $0.70 \mathrm{a}$ & $0.60 \mathrm{a}$ & $0.60 \mathrm{~b}$ & $0.63 \mathrm{a}$ & $0.60 \mathrm{~b}$ & $0.55 \mathrm{a}$ & $0.58 \mathrm{a}$ & $0.70 \mathrm{a}$ \\
\hline BGP029 & $0.55 b$ & $0.40 \mathrm{~b}$ & $0.60 \mathrm{~b}$ & $0.52 b$ & $0.45 b$ & $0.60 \mathrm{a}$ & $0.53 \mathrm{a}$ & $0.60 \mathrm{a}$ \\
\hline BGP033 & $0.55 b$ & $0.60 \mathrm{a}$ & $0.53 b$ & $0.56 \mathrm{a}$ & $0.75 a$ & $0.55 \mathrm{a}$ & $0.65 \mathrm{a}$ & $0.95 \mathrm{a}$ \\
\hline BGP034 & $0.70 \mathrm{a}$ & $0.60 \mathrm{a}$ & $0.73 \mathrm{a}$ & $0.68 \mathrm{a}$ & $0.80 \mathrm{a}$ & $0.60 \mathrm{a}$ & $0.70 \mathrm{a}$ & $0.70 \mathrm{a}$ \\
\hline BGP041 & $0.80 \mathrm{a}$ & $0.60 \mathrm{a}$ & $0.53 b$ & $0.64 \mathrm{a}$ & $0.65 a$ & $0.50 \mathrm{a}$ & $0.58 \mathrm{a}$ & $0.45 \mathrm{a}$ \\
\hline BGP043 & $0.70 \mathrm{a}$ & $0.40 \mathrm{~b}$ & $0.60 \mathrm{~b}$ & $0.57 \mathrm{a}$ & $0.80 \mathrm{a}$ & $0.55 \mathrm{a}$ & $0.68 \mathrm{a}$ & $0.85 a$ \\
\hline BGP044 & $0.40 \mathrm{~b}$ & $0.40 \mathrm{~b}$ & $0.67 \mathrm{a}$ & $0.49 \mathrm{~b}$ & $0.60 \mathrm{~b}$ & $0.65 \mathrm{a}$ & $0.63 \mathrm{a}$ & $0.70 \mathrm{a}$ \\
\hline BGP048 & $0.55 \mathrm{~b}$ & $0.67 \mathrm{a}$ & $0.53 b$ & $0.58 \mathrm{a}$ & $0.70 \mathrm{a}$ & $0.60 \mathrm{a}$ & $0.65 \mathrm{a}$ & $0.50 \mathrm{a}$ \\
\hline BGP051 & $0.60 \mathrm{a}$ & $0.73 a$ & $0.80 \mathrm{a}$ & $0.71 \mathrm{a}$ & $0.70 \mathrm{a}$ & $0.50 \mathrm{a}$ & $0.60 \mathrm{a}$ & $0.85 a$ \\
\hline BGP064 & $0.50 \mathrm{~b}$ & $0.60 \mathrm{a}$ & $0.80 \mathrm{a}$ & $0.63 \mathrm{a}$ & $0.80 \mathrm{a}$ & $0.80 \mathrm{a}$ & $0.80 \mathrm{a}$ & $0.30 \mathrm{a}$ \\
\hline BGP071 & $0.50 \mathrm{~b}$ & $0.47 b$ & $0.47 b$ & $0.48 b$ & $0.65 a$ & $0.50 \mathrm{a}$ & $0.58 \mathrm{a}$ & $0.50 \mathrm{a}$ \\
\hline BGP078 & $0.50 \mathrm{~b}$ & $0.73 a$ & $0.53 b$ & $0.59 \mathrm{a}$ & $0.70 \mathrm{a}$ & $0.40 \mathrm{a}$ & $0.55 \mathrm{a}$ & $0.65 a$ \\
\hline BGP079 & $0.65 a$ & $0.47 b$ & $0.47 b$ & $0.53 b$ & $0.80 \mathrm{a}$ & $0.40 \mathrm{a}$ & $0.60 \mathrm{a}$ & $0.85 a$ \\
\hline BGP092 & $0.50 \mathrm{~b}$ & $0.33 b$ & $0.67 \mathrm{a}$ & $0.50 \mathrm{~b}$ & $0.55 b$ & $0.50 \mathrm{a}$ & $0.53 \mathrm{a}$ & $0.85 a$ \\
\hline BGP094 & $0.85 a$ & $0.40 \mathrm{~b}$ & $0.80 \mathrm{a}$ & $0.68 \mathrm{a}$ & $0.70 \mathrm{a}$ & $0.60 \mathrm{a}$ & $0.65 a$ & $0.55 \mathrm{a}$ \\
\hline BGP116 & $0.70 \mathrm{a}$ & $0.33 b$ & $0.47 b$ & $0.50 \mathrm{~b}$ & $0.60 \mathrm{~b}$ & $0.55 \mathrm{a}$ & $0.58 \mathrm{a}$ & $0.80 \mathrm{a}$ \\
\hline BGP121 & $0.55 b$ & $0.53 \mathrm{a}$ & $0.47 b$ & $0.52 b$ & $0.55 b$ & $0.65 \mathrm{a}$ & $0.60 \mathrm{a}$ & $0.65 \mathrm{a}$ \\
\hline BGP123 & $0.50 \mathrm{~b}$ & $0.47 \mathrm{~b}$ & $0.53 b$ & $0.50 \mathrm{~b}$ & $0.75 a$ & $0.50 \mathrm{a}$ & $0.63 a$ & $0.70 \mathrm{a}$ \\
\hline BGP158 & $0.30 \mathrm{~b}$ & $0.53 a$ & $0.33 b$ & $0.39 b$ & $0.65 a$ & $0.65 a$ & $0.65 a$ & $0.65 a$ \\
\hline BGP168 & $0.45 b$ & $0.33 b$ & $0.33 b$ & $0.37 b$ & $0.65 a$ & $0.40 \mathrm{a}$ & $0.53 \mathrm{a}$ & $0.35 \mathrm{a}$ \\
\hline BGP181 & $0.75 \mathrm{a}$ & $0.73 a$ & $0.53 b$ & $0.67 \mathrm{a}$ & $0.75 a$ & $0.35 \mathrm{a}$ & $0.55 \mathrm{a}$ & $0.85 \mathrm{a}$ \\
\hline BGP185 & $0.50 \mathrm{~b}$ & $0.60 \mathrm{a}$ & $0.53 b$ & $0.54 b$ & $0.70 \mathrm{a}$ & $0.50 \mathrm{a}$ & $0.60 \mathrm{a}$ & $0.70 \mathrm{a}$ \\
\hline BGP186 & $0.45 b$ & $0.40 \mathrm{~b}$ & $0.67 \mathrm{a}$ & $0.51 b$ & $0.65 a$ & $0.70 \mathrm{a}$ & $0.68 \mathrm{a}$ & $0.80 \mathrm{a}$ \\
\hline BGP188 & $0.45 b$ & $0.40 \mathrm{~b}$ & $0.40 \mathrm{~b}$ & $0.42 b$ & $0.40 \mathrm{~b}$ & $0.50 \mathrm{a}$ & $0.45 \mathrm{a}$ & $0.95 \mathrm{a}$ \\
\hline BGP205 & $0.45 b$ & $0.47 \mathrm{~b}$ & $0.47 b$ & $0.46 \mathrm{~b}$ & $0.65 a$ & $0.35 \mathrm{a}$ & $0.50 \mathrm{a}$ & $0.65 a$ \\
\hline BGP208 & $0.45 b$ & $0.33 b$ & $0.73 a$ & $0.51 b$ & $0.60 \mathrm{~b}$ & $0.35 \mathrm{a}$ & $0.48 \mathrm{a}$ & $0.90 \mathrm{a}$ \\
\hline BGP222 & $0.65 a$ & $0.67 \mathrm{a}$ & $0.53 b$ & $0.62 \mathrm{a}$ & $0.65 a$ & $0.45 \mathrm{a}$ & $0.55 \mathrm{a}$ & $0.70 \mathrm{a}$ \\
\hline BGP227 & $0.80 \mathrm{a}$ & $0.40 \mathrm{~b}$ & $0.73 a$ & $0.64 a$ & $0.55 b$ & $0.60 \mathrm{a}$ & $0.58 \mathrm{a}$ & $0.45 a$ \\
\hline BGP277 & $0.60 \mathrm{a}$ & $0.40 \mathrm{~b}$ & $0.33 b$ & $0.44 b$ & $0.55 b$ & $0.45 a$ & $0.50 \mathrm{a}$ & $0.45 \mathrm{a}$ \\
\hline BGP311 & $0.50 \mathrm{~b}$ & $0.47 \mathrm{~b}$ & $0.87 \mathrm{a}$ & $0.61 \mathrm{a}$ & $0.55 b$ & $0.45 \mathrm{a}$ & $0.50 \mathrm{a}$ & $0.65 a$ \\
\hline $\begin{array}{l}\text { BRS Gigante } \\
\text { Amarelo }\end{array}$ & $0.65 \mathrm{a}$ & $0.47 b$ & $0.60 \mathrm{~b}$ & $0.57 \mathrm{a}$ & $0.70 \mathrm{a}$ & $0.50 \mathrm{a}$ & $0.60 \mathrm{a}$ & $0.50 \mathrm{a}$ \\
\hline $\mathrm{CV}$ & $35 \%$ & $40 \%$ & $36 \%$ & $23 \%$ & $28 \%$ & $37 \%$ & $22 \%$ & $33 \%$ \\
\hline BSH & $46 \%$ & $50 \%$ & $57 \%$ & $54 \%$ & $45 \%$ & $36 \%$ & $41 \%$ & $65 \%$ \\
\hline
\end{tabular}

\section{Discussion}

Considering the need to release cultivars exhibiting combined resistance to the major diseases that affect passion fruit, the results obtained in this study will contribute to passion fruit pre-breeding activities aimed at intensifying the use of the accessions available in the active germplasm bank of EMBRAPA. From this 
(a)

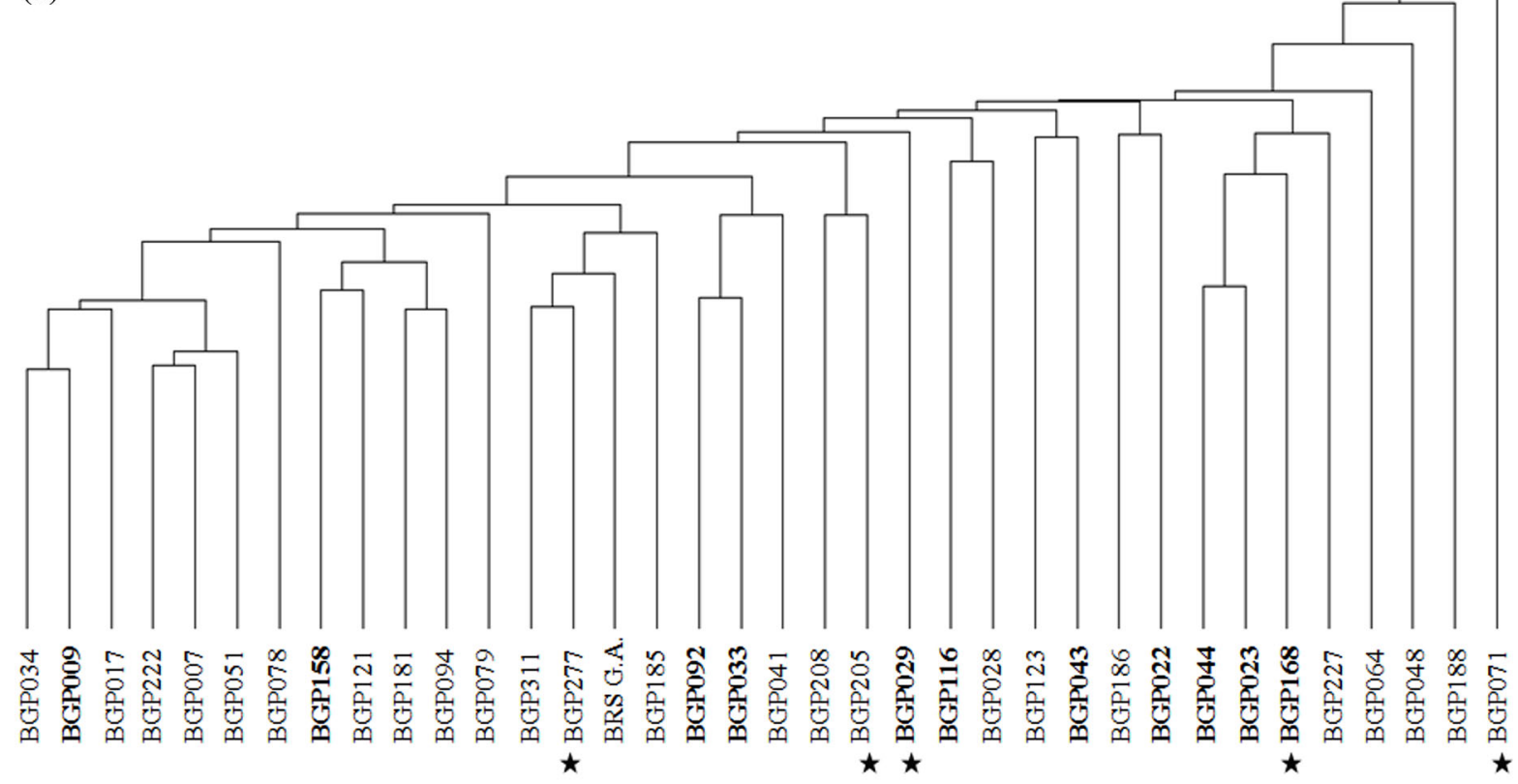

(b)

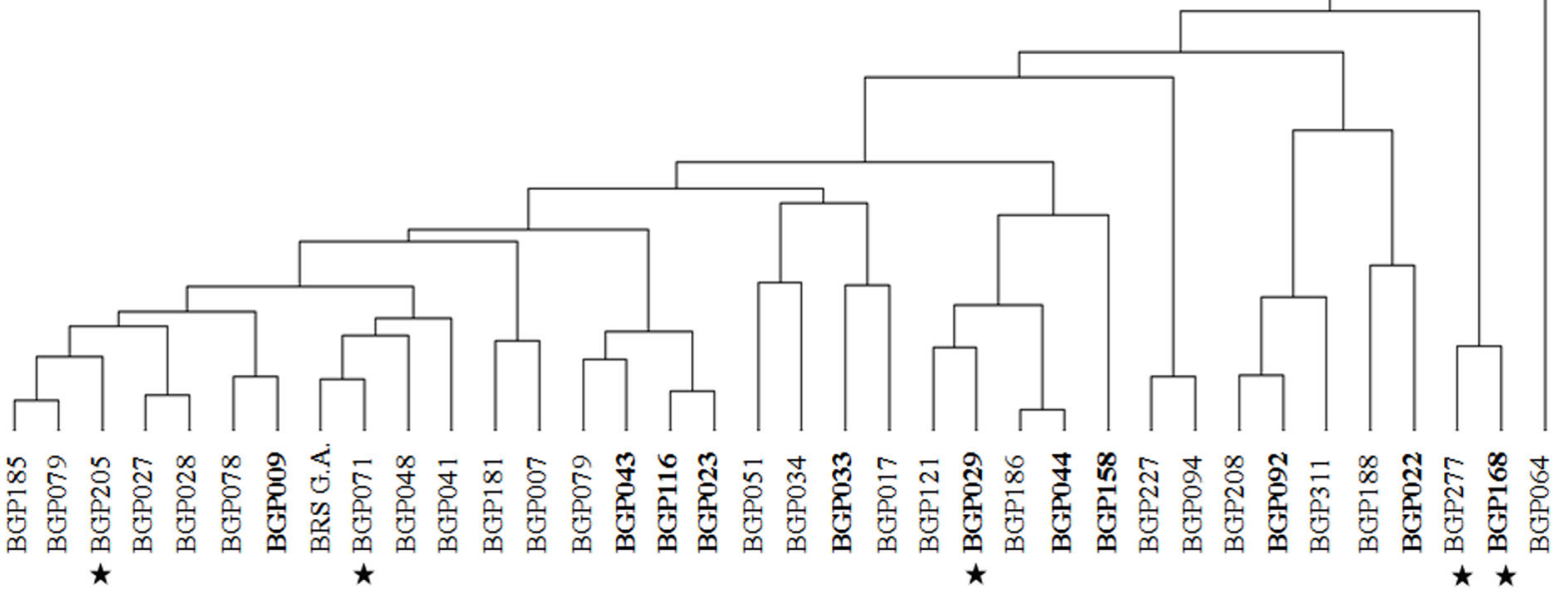

Fig. 3 Dendrograms obtained through UPGMA cluster construction based on the modified Rogers' distance (Wright 1978) for microsatellite data (a) and forthe Mahalanobis distance for disease reaction data $(\mathbf{b})$, considering 36 passion fruit accessions

perspective, the estimates of molecular genetic variation and of the gradient of disease resistance observed for the accessions enable the identification of preferred crossings to establish populations that are useful in both from the germplasm bank of EMBRAPA Cassava and Fruits, Cruz das Almas, Bahia, Brazil. Note Accessionsthat presented a lower intensity of symptoms for the three diseases evaluated in this study are identified with a star

recurrent selection cycles and for genetic map construction and QTL identification.

The average number of alleles (5.52 per locus)observed in the 36 accessions (Table 3 ) is consistent with 
Table 5 Descriptive presentation of the average intensity of symptoms, number of microsatellite alleles (Na) and Nei's genetic diversity $\left(\mathrm{H}_{\mathrm{E}}\right)$ for the different groups formed after classification of the severity of symptoms in 36 passion fruit accessions for the three evaluated diseases

a Accessions of group 1 are also part of the accession list of group 2, accessions of group 1 and 2 are part of the accession list of group 3, as well as accessions from group 1, 2 and 3 are part of accessions list of the group 4

$B R S$-GA BRS Gigante

Amarelo

b Details of the accessions are available in the Supplementary Material SM 1

\begin{tabular}{|c|c|c|c|c|c|}
\hline Diseases & $\begin{array}{l}\text { Percentage of } \\
\text { accessions selected }^{\mathrm{a}}\end{array}$ & Symptoms & $\mathrm{Na}$ & $\mathrm{H}_{\mathrm{E}}$ & Set of accessions ${ }^{\mathrm{b}}$ \\
\hline \multirow[t]{4}{*}{$\begin{array}{l}\text { Woodiness } \\
\text { virus }\end{array}$} & Group $1(25 \%)$ & 0.45 & 105 & 0.52 & $\begin{array}{l}\text { BGP023, 044, 071, 092, 158, } \\
\quad 168,188,205,277\end{array}$ \\
\hline & Group $2(50 \%)$ & 0.48 & 119 & 0.51 & $\begin{array}{l}\text { BGP022, 029, 079, 116, 121, } \\
\quad 123,185,186,208\end{array}$ \\
\hline & Group $3(75 \%)$ & 0.52 & 121 & 0.50 & $\begin{array}{c}\text { BGP017, 028, 033, 043, 048, } \\
078,222,311, \text { BRS-GA }\end{array}$ \\
\hline & Group $4(100 \%)$ & 0.55 & 127 & 0.49 & $\begin{array}{l}\text { BGP007, 009, 034, 041, 051, } \\
\text { 064, 094, 181, } 227\end{array}$ \\
\hline \multirow[t]{4}{*}{ Scab } & Group $1(25 \%)$ & 0.49 & 99 & 0.48 & $\begin{array}{l}\text { BGP009, 022, 029, 092, 188, } \\
\quad 205,208,277,311\end{array}$ \\
\hline & Group $2(50 \%)$ & 0.53 & 118 & 0.50 & $\begin{array}{l}\text { BGP017, 028, 041, 071, 078, } \\
116,168,181,222\end{array}$ \\
\hline & Group $3(75 \%)$ & 0.55 & 125 & 0.50 & $\begin{array}{c}\text { BGP007, 023, 044, 051, 079, } \\
121,185,227, \text { BRS-GA }\end{array}$ \\
\hline & Group $4(100 \%)$ & 0.58 & 127 & 0.49 & $\begin{array}{l}\text { BGP033, 034, 043, 048, 064, } \\
094,123,158,186\end{array}$ \\
\hline \multirow[t]{4}{*}{ Anthracnose } & Group $1(25 \%)$ & 0.45 & 98 & 0.48 & $\begin{array}{c}\text { BGP009, 041, 048, 064, 071, } \\
168,227,277, \text { BRS-GA }\end{array}$ \\
\hline & Group $2(50 \%)$ & 0.55 & 113 & 0.49 & $\begin{array}{l}\text { BGP007, 028, 029, 078, 094, } \\
\quad 121,158,205,311\end{array}$ \\
\hline & Group $3(75 \%)$ & 0.61 & 120 & 0.49 & $\begin{array}{l}\text { BGP017, 023, 034, 044, 116, } \\
\quad 123,185,186,222\end{array}$ \\
\hline & Group $4(100 \%)$ & 0.68 & 127 & 0.49 & $\begin{array}{l}\text { BGP022, 033, 043, 051, 079, } \\
092,181,188,208\end{array}$ \\
\hline
\end{tabular}

Table 6 Presentation of the symptoms of three diseases in 25 yellow passion fruit and 11 purple passion fruit accessions, including the average intensity, standard deviation and results of the Mann-Whitney test

\begin{tabular}{llll}
\hline Disease & \multicolumn{2}{l}{$\begin{array}{l}\text { Average intensity of the } \\
\text { symptoms }\end{array}$} & Mann-Whitney \\
\cline { 2 - 3 } & Yellow & Purple & \\
\hline $\begin{array}{l}\text { Woodiness } \\
\text { virus }\end{array}$ & $0.57( \pm 0.08)$ & $0.51( \pm 0.07)$ & $\mathrm{Z}$ \\
$\begin{array}{l}\text { Scab } \\
\text { Antharcnose }\end{array}$ & $0.66( \pm 0.17)$ & $0.72( \pm 0.18)$ & Z value $=2.18^{*}$ \\
& $0.59( \pm 0.07)$ & $0.58( \pm 0.08)$ & Z value $=0.11$ \\
& & &
\end{tabular}

* Differ significantly by the Mann-Whitney test at a $5 \%$ probability $(p$ value observed $=0.014$ )

the values obtained in previous genetic characterizations performed in passion fruit using microsatellite markers (Cerqueira-Silva et al. 2014c). The few such studies conducted to date have indicated a low number of alleles at the loci characterized for the commercial species $P$. edulis (4.7) (Oliveira et al. 2005; CerqueiraSilva et al. 2014b) and P. alata (3.1) (Padua et al. 2005).
For wild passion fruit species, such as $P$. contracta, $P$. cincinnata and $P$. setacea, the average number of alleles per locus has also been found to be low, ranging from 2.8 to 4.9 (Cerqueira-Silva et al. 2014b; Cazé et al. 2012). In addition, the number of alleles detected in passion fruit undergoing recurrent selection has beenreported to be fewer than three alleles per locus (Reis et al. 2011). Considering the apparent pattern of low diversity at SSR loci observed in passion fruit (Cerqueira-Silva et al. 2014c), the number of alleles identified in the set of evaluated accessions is considered favorable for establishing strategies for selecting and forming base populations for breeding.

The obtained Nei's genetic diversity values (average of 0.49) were consistent with the expectation for outcrossing species and with the values observed in a previous study for $P$. edulis (Oliveira et al. 2005). The mean value of $\mathrm{F}(0.14)$ can be interpreted as indicating a loss of heterozygotes and corroborates the higher values obtained for $\mathrm{H}_{\mathrm{E}}$ than for $\mathrm{H}_{0}$. These results may be partly explained by the origins of the accessions 


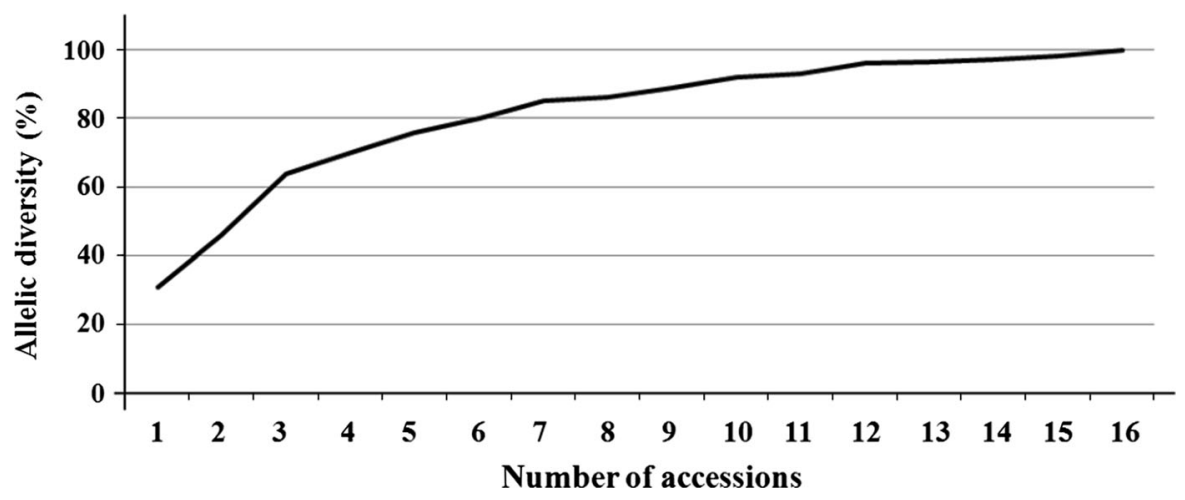

Fig. 4 Allelic diversity as a function of the number of accessions included in the core collection of passion fruit (Passiflora edulis Sims). Note The order of theaccessions included in the core collection was as follows: BGP007;

found in germplasm banks; i.e., thetransport of seeds among production regions and the use of seeds produced by a given plantation for its next generation of seedlings are common practices, particularly for commercial passion fruit species (Santos et al. 2011).

The amplitude of the observed values for the six measured variables $(0.65$, considering a scale from 0 to 1) (Fig. 2) and the significant results of ANOVA $(p<0.05)$ for all six variables indicate the existence of variability that is potentially useful for breeding programs, particularly in the early stages of mass selection and the establishment of progenies for recurrent selection. The results obtained from the univariate test for the comparison of means (ScottKnott) corroborate the existence of variability in the reaction of the passion fruit accessions to at least four of the six considered variables (Table 4).

Descriptions of the reactions of $P$. edulis (yellow and purple shell) to different pathogens are available in the literature and indicate the existence of both variability available for selection in collections and accessions maintained in germplasm banks (Oliveira et al. 2013; Silva et al. 2013; Cerqueira-Silva et al. 2008; Junqueira et al. 2006) and low disease resistance or tolerance in passion fruit cultivars (Batistti et al. 2013; Fischer et al. 2010; Junqueira et al. 2003).

The low correlations observed among the six variables considered in evaluating the reactions of the passion fruit accessions to the three studied diseases $(-0.12<\mathrm{r}<0.36)$ indicate possible difficulties in obtaining balanced genetic gains using direct selection procedures, given the trend toward unwanted losses of
BGP208; BGP041; BGP023; BGP028; BGP123; BGP071; BGP116; BGP188; BGP185; BGP181; BGP051; BGP168; BGP064; BGP017; BGP079

genetic gains due to the existence of uncorrelated features. Similar correlation results were observed by Freitas et al. (2012) when evaluating the same six variables among 43 accessions of yellow passion fruit. However, the obtained correlation values do not prevent the use of selection indices, particularly because no significant negative correlations were found. The application of different selection indices for agronomic production traits and disease resistance was recently evaluated in passion fruit accessions (Freitas et al. 2012), and an imbalance was observed in the genetic gains associated with production characteristics and with levels of disease resistance when using the strategy of direct selection. In this work, Freitas et al. (2012) also detected more balanced genetic gains using the Mulamba and Mock index.

The variability estimates obtained from both the modified Rogers' distance (Wright 1978) and the Mahalanobis distance allowed genetic differentiation of all the evaluated accessions (Fig. 3). Estimates of genetic distance between passion fruit accessions or within natural passion fruit populations based on microsatellite loci are in their incipient stages, with the results being restricted to recent diversity estimates, such as estimates from the SSR locus cross-amplification (Oliveira et al. 2013). The use of these markers has also contributed tothe monitoringof the variability present in segregating populations undergoing recurrent selection (Reis et al. 2012, 2011) and to developing genetic maps for $P$. edulis (Oliveira et al. 2005) and for P. alata (Pereira et al. 2013).

Based on the obtained estimates of the modified Rogers' distance, it is possible to identify pairs of 
convergent and divergent accessions, highlighting the pair BGP009 and BGP034 (or BGP051), with a distance value of 0.21 , and the pair BGP071 and BGP186, with a distance value of 0.62 . Characterizing the genetic distance within collections and germplasm banks based on molecular markers contributes to both the monitoring of variability and the definition of preferred crosses to be performed at different stages of a breeding program. Genetically divergent accessions, such as BGP071 and BGP186, may beuseful in establishing segregating populations and in producing hybrids with a potential heterosis effect. In turn, identifying genetically similar accessions can reduce the time and number of crossings required in backcrossing cycles whose goal is to introgress specific traits into cultivars of interest.

In turn, extreme values were observed for the Mahalanobis distance between the accession pair BGP044 and BGP186 (0.38) and the accession pair BGP064 and BGP188 (22.9). Considering the low correlations found among the reactions of the accessions to the different diseases and the consequent difficulty of applying a direct selection strategy grounded in individual characteristics, we understand that identifying convergent crosses potentiates the average gain of resistance to diseases. In turn, the use of divergent accessions, based on the Mahalanobis distance, can be useful in generating mapping populations, which increases the possibility of identifying QTLs for resistance, at least for the studied diseases.

Variability data based on molecular markers and the reactions of accessions to diseases potentiate the establishment of populations showing high genetic variability (considering divergent values for the modified Rogers' distance) and displaying reduced variance in their reactions to the evaluated diseases (considering convergent values for the Mahalanobis distance). Freitas et al. (2012) indicated that maximizing the variability among the accessions used in the composition of base populations undergoing recurrent selection is a strategy employed to avoid unwanted narrowing of the available genetic base in the initial selection cycles.

The low correlations observed between the matrices of distance estimates obtained from the molecular data (such as microsatellite markers) and the agronomic data (such as the reactions of the accessions to disease) ( $r=0.16$; Mantel test with 10,000 simulations) are expected due to the nature of these data.
Most of the observed variability in the molecular markers is, by definition, nonadaptive, unlike phenotypic characteristics, which are affected by selection and influenced by interactions with the environment. Reis et al. (2012) reported similar results when comparing data from thegenotyping and phenotypingofpassion fruit undergoing recurrent selection cycles.

Classification of the accessions into groups according to the percentages of selection $(25,50,75$ and $100 \%$ ) considering the rank of the accessions based on the ascending order of symptom intensity for the three diseases (Table 5), contributed to defining the accessions to be prioritized in breeding programs dedicated to resistance. As the accessions classified as belonging to groups 1 and 2 (Table 5) exhibited the lowest intensities of symptoms (average symptom values ranging from 0.48 , for woodiness virus, to 0.55 , for anthracnose) and retained, on average, $85 \%$ of the alleles identified in the microsatellite loci, these accessions should be prioritized in the composition of breeding populations. These results hold greater relevance when compared with the set of accessions suggested for use in a core collection considering only genotyping data from microsatellite loci (Fig. 4). The average values of symptoms observed in this accession collection varied between 0.55 , for woodiness virus, and 0.70 , for anthracnose.

Considering that a core collection should retain from 5 to $20 \%$ of the accessions available in a collection and should represent at least $70 \%$ of the existing diversity (Brown et al. 1987; Nass 2011), both the set of accessions suggested by the COREFINDER program (Fig. 4) and the accessions from groups 1 and 2 (Table 5) are suitable for forming core and working collections. Identifying accessions with favorable characteristics for passion fruit genetic breeding is of great importance because studies conducted by Freitas et al. (2011) on Passiflora genetic resources demonstrated the need for genetic recombination among accessions to further explore and selectsuperior progenies, asaccessions of passion fruit combining the quantitative and qualitative characteristics favorable for production were not identified by these authors.

Notably, BGP029, 071, 168, 205 and 277 were ranked among the accessions displaying weaker symptoms for the three evaluated diseases when considering a selection percentage of $50 \%$. Assuming a more restrictive selection percentage (25\%), 
accessions BGP029 and BGP205 were both classified into group 1, displaying a low intensity of symptoms for woodiness virus and scab. In turn, accession BGP168 was classified into group 1 based on its symptoms related to woodiness virus and anthracnose. Finally, accession BGP277 was the only accession classified into group 1 for all three evaluated diseases.

Although few studies have focused on the agronomic characterization of accessions maintained in collections and germplasm banks, important associations can be identified based on the available publications. Data related to the resistance of passion fruit to Fusarium oxysporum f. sp. passiflorae (Silva et al. 2013) indicate that the BGP208 and BGP029 accessions, which were classified into the groups showing weaker symptoms for woodiness virus and scab, are also resistant to $F$. oxysporum. In turn, agronomic characterizations performed by Reis et al. (2011) indicate that BGP208 presents high fruit production (80-98 fruit per plant) compared with other accessions in the germplasm bank.

The 'BRS Gigante Amarelo' cultivar was classified into group 3 due to its reactions to both woodiness virus and scab because this cultivar was more susceptible to these diseases than most of the accessions included in this study (Table 5). Considering anthracnose, however, the 'BRS Gigante Amarelo' cultivar was classified into group 1 because of being less susceptible to this disease. These results are consistent with the data available in the literature (Batistti et al. 2013; Fischer et al. 2010; Junqueira et al. 2003) indicating the susceptibility of passion fruit cultivars to the most important diseases related to fruit culture. In this context, different authors have indicated the need for research focused on increasing the resistance of existing cultivars or on developing new cultivars using both intraspecific and interspecific crosses (Faleiro et al. 2011; Meletti et al. 2005; Faleiro et al. 2005). The genetic variability and the gradient of resistance identified in this study reinforce the possibility, which was also presented by Oliveira et al. (2013), of employing intraspecific crossing as a strategy to reduce the susceptibility of passion fruit cultivars to the primary diseases that affect passion fruit culture.

Although significant genetic structure was not observed among the purple and yellow passion fruit accessions (Nei's $\mathrm{G}_{\mathrm{st}}=0.012$ ) and although no clear evidence of subgroups (Fig. 3) was observed, the private alleles identified among these groups of accessions could be useful in monitoring hybrids between these variants of $P$. edulis. In addition, the results of the comparison of averages (Table 6) suggest that the purple passion fruit accessions can be prioritized in the search for resistance to woodiness virus. Additionally, a tendency toward reduced anthracnose symptoms was observed in the yellow passion fruit accessions.

Acknowledgments The authors thanks Dr. LCDH Conceição for suggestions, and the Empresa Brasileira de Pesquisa Agropecuaria (Macro-ProjectPhase III), Fundação de Amparo à Pesquisa do Estado da Bahia (FAPESB, RED0004/2012), Fundação de Amparo á Pesquisa de São Paulo (FAPESP, 2008/52197-4), Conselho de Aperfeiçoamento de Pessoal de Nível Superior (CAPES, PROCAD-NF2008), and Conselho Nacional de Desenvolvimento Científico e Tecnológico (CNPq) for research fellowships awarded to APS. This work is part of the doctoral thesis of the first author in the Programa de PósGraduação em Genética e Biologia Molecular at the Universidade Estadual de Campinas/UNICAMP.

Open Access This article is distributed under the terms of the Creative Commons Attribution License which permits any use, distribution, and reproduction in any medium, provided the original author(s) and the source are credited.

\section{References}

Ayres M, Ayres M Jr, Ayres DL, Santos AA (2007) BIOESTAT-Aplicações estatísticas nas áreas das Ciências BioMédicas. Mamirauá, Belém

Batistti M, Krause W, Baréa M, Araujo DV, Palú EG (2013) Resistência à verrugose de cultivares de maracujazeiro amarelo sob diferentes métodos de inoculação. Enciclopédia Biosfera 9:2710-2720

Bellon G, Faleiro FG, Junqueira KP, Junqueira NTV, Santos EC, Braga MF, Guimarães CT (2007) Geneticvariabilityofwildandcommercialpassionfruit (Passiflora edulis Sims.) accessionsusing RAPD markers. Rev Bras Frutic 29:124-127. doi:10.1590/S0100-29452007000100027

Bernacci LC, Soares-Scott MD, Junqueira NTV, Passos IRS, Meletti LMM (2008) Passiflora edulis Sims: the correct taxonomic way to cite the yellow passion fruit (and of others colors). Rev Bras Frutic 30:566-576. doi:10.1590/ S0100-29452008000200053

Borges RS, Scaranari C, Nicoli AM, Coelho RR (2005) Novas variedades: validação e transferência de tecnologia. In Maracujá: germoplasma e melhoramento genético. In: Faleiro FG, Junqueira NTV, Braga MF (eds) Embrapa Cerrados: Planaltina, pp 618-640

Brown AHD, Grace JP, Speer SS (1987) Designation of a "core" collection of perennial Glycine. Soybean Genet Newslett 14:59-70

Carneiro MS, Camargo LEA, Coelho ASG, Vencovsky R, Leite RP, Stenzel NM, Vieira MLC (2002) RAPD-based genetic 
linkage maps of yellow passion fruit (Passiflora edulis Sims. f. flavicarpa Deg.). Genome 45:670-678

Cazé ALR, Kriedt RA, Beheregaray LB, Bonatto SL, Freitas LB (2012) Isolation and characterization of microsatellite markers for Passiflora contracta. Int $\mathrm{J}$ Mol Sci 13:11343-11348. doi:10.3390/ijms130911343

Cerqueira-Silva CBM, Moreira CN, Figueira AR, Corrêa RX, Oliveira AC (2008) Detection of a resistance gradient to Passion fruit woodiness virus and selection of 'yellow' passion fruit plants under field conditions. Genet Mol Res 7:1209-1216

Cerqueira-Silva CBM, Conceição LDHCS, Cardoso-Silva CB, Pereira AS et al (2010a) Genetic diversity in yellow passion fruit (Passiflora edulis Sims) based on RAPD. Crop Breed Appl Biotechnol 10:154-159

Cerqueira-silva CBM, Conceição LDHCS, Santos ESL, Cardoso-silva CB, Pereira AS, Oliveira AC, Corrêa RX (2010b) Genetic variability in wild genotypes of Passiflora cincinnata based on RAPD markers. Genet Mol Res 9:2421-2428. doi:10.4238/vol9-4gmr981

Cerqueira-Silva CBM, Cardoso-Silva CB, Santos ESL, Conceição LDHCS, Pereira AS, Oliveira AC, Corrêia RX (2010c) Genetic diversity in wild species of passion fruit (Passifloratrintae) based on molecular markers. Genet Mol Res 9:2130-2137

Cerqueira-Silva CBM, Santos ESL, Conceição LDHCS, Cardoso-Silva CB, Pereira AS, Oliveira AC, Corrêa RX (2012a) Short Communication Genetic variation in a wild population of the 'sleep passion fruit (Passiflora setacea) based on molecular markers. Genet Mol Res 11:731-738. doi:10.4238/2012.March.22.3

Cerqueira-Silva CBM, Santos ESL, Souza AM, Mori GM, Oliveira EJ, Corrêa RX, Souza AP (2012b) Development and characterization of microsatellite markers for the wild South American Passifloracincinnata(Passifloraceae). Am J Bot 99:e170-e172. doi:10.3732/ajb.1100477

Cerqueira-Silva CBM, Conceição LDHCS, Souza AP, Corrêa RX (2014a) A history of passion fruit woodiness disease with emphasis on the current situation in Brazil and prospects for Brazilian passion fruit cultivation. Eur $\mathbf{J}$ Plant Pathol 139:255-264. doi:10.1007/s10658-0140391-Z

Cerqueira-Silva CBM, Santos ESL, Vieira JGP, Mori GM, Jesus ON, Correa RX, Souza AP (2014b) New microsatellite markers for wild and commercial species of Passiflora (Passifloraceae) and cross-amplification. Appl Plant Sci 2:1-5. doi:10.3732/apps.1300061

Cerqueira-Silva CBM, Jesus ON, Santos ESL, Corrêa RX, Souza AP (2014c) Genetic breeding and diversity of the genus Passiflora: progress and perspectives in molecular and genetic studies. Int J Mol Sci 15: 17077-17103. doi:10. 3390/ijms150x000x

Cipriani G, Spadotto A, Jurman I, Gaspero G, Crespan M, Meneghetti S, Frare E, Vignani R, Cresti M, Morgante M et al (2010) The SSR-based molecular profile of 1005 grapevine (Vitis vinifera L.) accessions uncovers new synonymy and parentages and reveals a large admixture amongst varieties of different geographic origin. Theor Appl Genet 121:1569-1585

Conceição LDHCS, Belo GO, Souza MM, Santos SF, Cerqueira-Silva CBM, Correa RX (2011) Confirmation of cross- fertilization using molecular markers in ornamental passion flower hybrids. Genet Mol Res 10:47-52

Costa JL, Jesus ON, Oliveira GAF, Oliveira EJ (2012) Effect of selection on genetic variability in yellow passion fruit. Crop Breed Appl Biotechnol 12:253-260

Cruz CD (2006) Programa genes-Análise multivariada e simulação, 1st edn. Viçosa, Minas Gerais

Cruz CD (2008) Programa genes-Diversidade Genética, 1st edn. Viçosa, Minas Gerais

Doyle JJ, Doyle JL (1990) Isolation of plant DNA from fresh tissue. Focus 12:13-15

Faleiro FG, Junqueira NTV (2009) Passion fruit (Passiflora spp.) improvement using wild species. In: Mariante AS, Sampaio MJA, Inglis MCV (eds). The state of Braziĺs plant genetic resources. Second National Report. Conservation and Sustainable Utilization for food and agriculture. Embrapa TechnologicalInformation, Brasília, pp 101-106

Faleiro FG, Junqueira NTV, Braga MF (2005) Germoplasma e melhoramento genético do maracujazeiro: Desafios da pesquisa. In Maracujá: germoplasma e melhoramento genético In: Faleiro FG, Junqueira NTV, Braga MF (eds) Embrapa Cerrados: Planaltina, pp 187-210

Faleiro FG, Junqueira NTV, Braga MF and Peixoto JR (2011) Pré-melhoramento do maracujá. In: Lopes MA, Fávero AP, Ferreira MAJF, Faleiro FG, Folle SM, Guimarães EP (eds). Pré-melhoramento de plantas. Estado da arte e experiências de sucesso. Embrapa Informações Tecnologicas, Brasília,Brazil, pp 549-570

Faleiro FG, Oliveira EJ, Andrade SEM, Costa AM, Junqueira NTV (2012) Biotecnologia na cultura do maracujazeiro. In: Cançado GMA, LondeLN (eds). Biotecnologia aplicada à agropecuária. EPAMIG Sul de Minas, Caldas, pp 401-440

Ferreira ME, Rangel PHN (2011) Aporte biotecnológico ao prémelhoramento vegetal. In: Lopes MA, Fávero AP, Ferreira MAJF, Faleiro FG, Folle SM, Guimarães EP (eds). Pré-melhoramento de plantas. Estado da arte e experiências de sucesso. Embrapa Informações Tecnologicas, Brasília, pp 59-84

Fischer IH, Bueno CJ, Garcia MJM, Almeida AM (2010) Reação de maracujazeiro-amarelo ao complexo fusariose-nematoide de galha. Acta Sci 32:223-227. doi:10.4025/ actasciagron.v32i2.3445

Fonseca KG, Faleiro FG, Peixoto JR, Junqueira NTV, Silva MS, Bellon G, Junqueira KP, Vaz CF (2009) Recovery analysisofrecurrent genitor in sourpassionfruitthroughrapdmarkers. Rev Bras Frutic 31:145-153

Freitas JPX, Oliveira EJ, Neto AJC, Santos LR (2011) Evaluation of genetic resources of yellow passion fruit. Pesq Agropec Bras 46:1013-1020. doi:10.1590/S0100-204X2011000900007

Freitas JPX, Oliveira EJ, Jesus ON, Neto AJC, Santos LR (2012) Development of a base population for recurrent selection in yellow passion fruit using selection indexes. PesqAgropec Bras 47:393-401. doi:10.1590/S0100-204X2012000300011

IBGE_-Diretoria de Pesquisas, Coordenação de Agropecuária, Produção Agrícola Municipal, 2012. Available online: http://www.ibge.gov.br/home/estatistica/economia/pam/2012/ default_perm_xls.shtm. Accessed 14 Mar 2014

Junqueira NTV, Anjos JRN, Silva ANP, Chaves RC, Gomes AC (2003) Reaction to diseases and yield of eleven cultivars of sour-passion fruit cultivated with no pesticides. Pesq Agropec Bras38:1005-1010. doi:10.1590/S0100-204X20030 00800014 
Junqueira NTV, Lage DAC, Braga MF, Peixoto JR, Borges TA, Andrade SRM (2006) Reaction to diseases and yield of a passion fruit clone propagated by cuttings and grafting on rooted-herbaceous cuttings of wild Passiflora specie. Rev Bras Frutic 28:97-100. doi:10.1590/S0100-2945200600 0100027

Junqueira KP, Faleiro FG, Ramos JD, Bellon G, Junqueira NTV, Braga MF (2007) Genetic variability of wild passion fruit determined by molecular markers. Rev Bras Frutic29:571-575. doi:10.1590/S0100-29452007000300030

Junqueira KP, Faleiro FG, Junqueira NTV, Bellon G, Ramos JD, Braga MF, Souza LS (2008) Confirmation of interspecific hybrids in passiflora using molecular markers. Rev Bras Frutic 30:191-196. doi:10.1590/S0100-29452008000100035

Lopes R, Lopes MTG, Carneiro MS, Matta FP, Camargo LEA, Vieira MLC (2006) Linkage and mapping of resistance genes to Xanthomonasaxonopodispv. passiflorae in yellow passion fruit. Genome 49:17-29. doi:10.1139/G05-081

Meletti LMM, Soares-Scott MD, Bernacci LC, Passos IRS (2005) Melhoramento genético do maracujá: passado e futuro. In: Faleiro FG, Junqueira NTV, Braga MF (eds) Maracujá: germoplasma e melhoramento genético. Planaltina, Brasília, pp 55-78

Miller MP (1997) Tools for population genetics analyses (TFPGA) 1.3: A Windows program for the analysis of allozyme and molecular population genetic data, 1997. Disponível em: http://www.ccg.unam.mx/ vinuesa/tlem09/ docs/TFPGADOC.PDF. Acessed 21 Aug 2014

Nass LL (2011) Pré-melhoramento vegetal. In: Lopes MA, Fávero AP, Ferreira MAJF, Faleiro FG, Folle SM, Guimarães EP (eds) Pré-melhoramento de plantas. Estado da arte e experiências de sucesso. Embrapa Informações Tecnologicas, Brasilia, pp 23-38

Nass LL, Paterniani E (2000) Pre-breeding: a link between genetic resources and maize breeding. Scientia Agricola57:581-587. doi:10.1590/S0103-90162000000300035

Novaes QS, Rezende JAM (1999) Possível aplicação do DASELISA indireto na seleção de maracujazeiro tolerante ao "Passionfruit Woodiness Virus". Fitopatologia Brasileira 24:76-79

Oliveira EJ (2006) Desenvolvimento e uso de marcadores microssatélites para construção e integração de mapas genéticos de maracujá-amarelo (Passiflora edulis Sims $f$. flavicarpa Deg.). PhD Thesis, Escola Superior de Agricultura "Luiz de Queiroz", Piracicaba, São Paulo

Oliveira EJ, Padua JG, Zucchi MI, Camargo LEA, Fungaro MHP, Vieira MLC (2005) Development and characterization of microsatellite markers from the yellow passion fruit (Passiflora edulis f. flavicarpa). Mol Ecol Notes 5:331-333. doi:10.1111/j.1471-8286.2005.00917.x

Oliveira EJ, Vieira MLC, Garcia AAF, Munhoz CEF, Margarido GRA, Consoli L, Matta FP, Moraes MC (2008) An integrated molecular map of yellow passion fruit based on simultaneous maximum-likelihood estimation of linkage and linkage phases. J Am Soc Hort Sci 1133:35-41

Oliveira EJ, Soares TL, Barbosa CJ, Santos Filho HP, Jesus ON (2013). Disease severity from passion fruit to identify sources of resistance in field conditions. Rev Bras Frutic 35:485-492. doi:10.1590/S0100-29452013000200018

Ortiz DC, Bohórquez A, Duque MC, Tohme J, Cuéllar D, Vásquez TM (2012) Evaluating purple passion fruit
(Passiflora edulis Sims $f$. edulis) genetic variability in individuals from commercial plantations in Colombia. Genet Resour Crop Evol 59:1089-1099. doi:10.1007/ s10722-011-9745-y

Padua JG, Oliveira EJ, Zucchi MI, Oliveira GCX, Camargo LEA, Vieira MLC (2005) Isolation and characterization of microsatellite markers from the sweet passion fruit (Passifloraalata Curtis Passifloraceae). Mol Ecol Notes 5:863-865. doi:10.1111/j.1471-8286.2005.01090.x

Peakall R, Smouse PE (2012) GenAlEx 6.5: genetic analysis in Excel. Population genetic software for teaching and research-an update. Bioinformatics 28:2537-2539. doi:10. 1093/bioinformatics/bts460

Penha HA, Pereira GS, Zucchi MI, Diniz AL, Vieira MLC, Flachowsky H (2013) Development of microsatellite markers in sweet passion fruit, and identification of length and conformation polymorphisms within repeat sequences. Plant Breed 132:731-735. doi:10.1111/pbr.12083

Pereira GS, Nunes ES, Laperuta LDC, Braga MF, Penha HÁ, Diniz AL, Munhoz CF, Gazaffi R, Garcia AAF, Vieira MLC (2013) Molecular polymorphism and linkage analysis in sweet passion fruit, an outcrossing species. Ann ApplBiol 162:347-361. doi:10.1111/aab.12028

Perrier X, Jacquemoud-Collet JP (2006) DARwinsoftwarehttp://darwin.cirad.fr/. Accessed 05 March 2014)

Reis RV, Oliveira EJ, Viana AP, Pereira TNS, Pereira MG, Silva MG (2011) Genetic diversity in recurrent selection of yellow passion fruit detected by microsatellites markers. Pesq Agropec Bras 46:51-57. doi:10.1590/S0100-204X 2011000100007

Reis RV, Viana AP, Oliveira EJ, Silva MGM (2012) Phenotypic and molecular selection of yellow passion fruit progenies in the second cycle of recurrent selection. Crop Breed Appl Biotechnol 12:17-24. doi:10.1590/S1984-70332012000 100003

Santos AA (2013) Exploração de uma biblioteca genomica de Passiflora edulis f. flavicarpa por sequenciamento de BAC-ends. Dissertation, Escola Superior de Agricultura Luiz de Queiroz, Piracicaba

Santos LF, OliveiraEJ, Silva AS, Carvalho FM, Costa JL, Padua JG (2011) ISSR markers as a tool for the assessment of genetic diversity in Passiflora. Biochem Genet 49:540554. doi:10.1007/s10528-011-9429-5

Santos EA, Souza MM, Abreu PP, Conceição LDHCS, Araujo IS, Viana AP, Almeida AF, Freitas JCO (2012) Confirmation and characterization of interspecific hybrids of Passiflora L. (Passifloraceae) for ornamental use. Euphytica 184:389-399. doi:10.1007/s10681-011-0607-7

Silva AS, Oliveira EJ, Haddad F, Laranjeira FF, Jesus ON, Oliveira SAS, Costa MAPC, Freitas JPX(2013) IdentificationofpassionfruitgenotypesresistanttoFusariumoxysporumf. sp.passiflorae.Trop plant pathol38:236-242. doi:10.1590/S1982-56762013005000008

Viana AP, Pereira TNS, Pereira MG, Souza MM, Maldonado JVM, Amaral Junior AT (2003) Genetic diversity among yellow passion fruit commercial genotypes and among Passiflora species using RAPD. Rev Bras Frutic25: 489-493. doi:10.1590/S0100-29452003000300032

Wright S (1978) Evolution and the genetics of populations. Variability within and among natural populations, vol 4. University of Chicago Press, Chicago 